\title{
Mantle plume, large igneous provinces and lithospheric evolution
}

Earth's tectonic system is dominated by geologic processes that occur at the plate boundaries. However, plate interiors are not entirely quiet. This is manifested by intraplate deformation and by currently active volcanic systems, such as the Hawaii-Emperor volcanic chain, and many large flood basalt provinces, such as the Siberian traps that are far from plate boundaries. These phenomena, which can not be explained by plate tectonic theory, are instead related to mantle plumes which are long and narrow columns of hot materials arising from deep in the mantle, independent of plate movements. The mantle plume hypothesis therefore represents an important complement of plate tectonics in the Earth sciences.

Over the past few years, considerable debates have been launched on whether mantle plumes actually exist or not, the origin of large igneous provinces and the convection and chemistry of the Earth's interior. Given the significance of the scientific problem, an international conference on Continental Volcanism was held in Guangzhou, China, May 14th to 18th, 2006 (Episodes, Vol. 29, No. 3 , September, 2006). This conference, sponsored by the International Association of Volcanology and Chemistry of the Earth's Interior (IAVCEI), brought together over 200 international scientists of different disciplines worldwide to discuss and share their views on the causes and consequences of continental volcanism. A total of 132 oral presentations were given at the meeting, and 6 of these are selected for publication in Episodes with the focus on (1) large igneous provinces (LIP) and their dynamic triggers and economic/environmental impacts and (2) composition and origin of the subcontinental lithosphere (SCLM).

In response to the current plume debate, Campbell and Davies (Episodes, Vol. 29, No. 3, September, 2006) outlined a number of testable predictions of the plume hypothesis and made comprehensive tests including seismic tomography, presence or absence of domal uplift, and relative timing of rifting and magmatism. They promoted the hypothesis with supportive evidence from seismic images of deep thermal anomalies, well-constrained pre-volcanic uplift history, and the occurrence of picrites (high temperature melts) in most LIPs. It is concluded that the mantle plume theory remains a valid global framework for the understanding of intraplate tectonomagmatic and ore-forming processes, as well as continental assembly, breakup and rifting.

Franco Pirajno presents an updated overview of the relationships between mantle dynamics, intraplate tectono-magmatic processes and their associated ore systems. He focused on direct links, proxied by the emplacement of mafic-ultramafic magmas and indirectly in rift systems created by the impact of mantle plumes onto the base of the continental lithosphere. Following this approach, two end-members of mantle plume-related ore systems are categorized: (1) magma-associated, such as orthomagmatic Ni-Cu-PGE, $\mathrm{Cr}$ in mafic-ultramafic rocks and magmatic-hydrothermal ore systems ( $\mathrm{Sn}-\mathrm{W}, \mathrm{Fe}$ oxide-Cu-Au) in anorogenic A-type magmas; (2) hydrothermal systems powered the thermal energy that results from the emplacement of plume-derived melts into the crust.

Large Igneous Provinces have two main categories: mafic LIPs and silicic LIPs. Richard Ernst (Episodes, next issue) defines the mafic LIPs as massive $\left(>105 \mathrm{~km}^{3}\right)$ crustal emplacements of predominantly mafic ( $\mathrm{Mg}$ and $\mathrm{Fe}$ rich) extrusive and intrusive rocks which originate via processes other than "normal" seafloor spreading and subduction processes. This category includes classic continental flood basalts, oceanic plateaus, bimodal-rift (passive margin) related packages, as well as events mainly of Phanerozoic-Proterozoic age, where the plumbing system of dykes, sills and layered intrusions has been exposed by erosion. In the Archean, mafic LIPs may be repre- sented by the greenstone belts of the tholeiite-komatiite association. LIPs are associated with continental breakup, climatic change, extinction events and major ore deposits especially of Ni-Cu-PGE type.

It has been noted in recent years that some LIPs may have substantial felsic components, and some LIPs are dominantly silicic with only minor mafic components. Scott Bryan provided a timely instructive overview on silicic LIPs by outlining their basic characteristics such as dimensions, crustal setting, volcanic architecture and geochemistry. He attributed the difference between silicic LIPs and other mafic-dominated LIPs to different crustal setting. Given their large volume and peculiar plumbing system, silicic LIPs may represent an important target for precious metal mineralization, and silicic eruptions may leave significant impacts on environment.

The testing of a mantle plume model has been carried out in a case study of the late Permian Emeishan continental flood basalt province in southwest China. Yi-Gang Xu et al. evaluated data of various disciplines against prediction of the plume hypothesis. It is shown that 7 out of 9 most convincing arguments in support of mantle plumes are found in the Emeishan LIP. In particular, sedimentologic data show unequivocal evidence for a lithospheric doming event prior to the Emeishan volcanism, consistent with predictions of plume modeling. This, and the presence of high temperature magmas, the emplacement of immense volume of magmas over a short time span and the spatial variation in basalt geochemistry have provided strong support to the validity of the mantle plume hypothesis.

The paper by Griffin and O'Reilly challenges the widelyaccepted concept that Archean eclogite xenoliths represent the former oceanic crust and that cratons are formed by the thrust-stacking of oceanic lithospheres. By integrating element composition and $\mathrm{Li}$ $\mathrm{B}-\mathrm{Mg}-\mathrm{C}-\mathrm{O}$ isotopes, the authors argued that there is no unambiguous evidence that SCLM peridotites-eclogites represent subducted ocean-floor material. It is proposed that cratonic eclogites may have an origin by the ponding and cooling of magmas at a compositional/rheological boundary and melt-peridotite reaction zones. The idea expressed in this paper is provocative enough to stimulate further discussion on the origin of the thick, depleted roots of the SCLM underneath Archean cratons.

The guest editor likes to thank the contributors for their enthusiastic involvement and co-operation to bring out the issue in time. I also want to express my sincere thanks to Prof. Zhenyu Yang, Editor, for approving publication of these selected papers in Episodes and to Ms. Huaisu Zhang, assistant editor, for her valuable help and support during review process and final editing of the papers assembled in issue. Last but not least, those colleagues who extended their valuable time and co-operation in providing thoughtful comments are gratefully acknowledged.

\section{Yi-Gang $\mathrm{Xu}$}

Key Laboratory of Isotope Geochronology and Geochemistry Guangzhou Institute of Geochemistry

Chinese Academy of Sciences

510640 Wushan, Guangzhou

China 